\title{
Ritual Lamentation in the Irish Penitentials
}

\author{
Alexandra Bergholm it
}

check for updates

Citation: Bergholm, Alexandra. 2021. Ritual Lamentation in the Irish Penitentials. Religions 12: 207. https://doi.org/10.3390/rel12030207

Academic Editor: Samuel J. Youngs

Received: 22 February 2021

Accepted: 15 March 2021

Published: 18 March 2021

Publisher's Note: MDPI stays neutral with regard to jurisdictional claims in published maps and institutional affiliations.

Copyright: (C) 2021 by the author. Licensee MDPI, Basel, Switzerland. This article is an open access article distributed under the terms and conditions of the Creative Commons Attribution (CC BY) license (https:/ / creativecommons.org/licenses/by/ $4.0 /)$.
Department of Cultures, Study of Religions, University of Helsinki, 00014 Helsinki, Finland; alexandra.bergholm@helsinki.fi

\begin{abstract}
Some of the earliest references to ritual lamentation or keening in the early Irish sources are found in the penitential handbooks dated to around the seventh and eighth centuries. In previous scholarship, these passages have commonly been interpreted as evidence of the continuous attempts of the Church to curb pagan practices among the 'nominally Christian' populace, thus assuming that such regulations were primarily used as a means of social control. This article examines the wider theological and intellectual context of these texts, by focusing in particular on the influence of the Old Testament on early Irish ecclesiastical writing. It will be argued that the demonstrable preoccupation of these sources with issues such as ritual purity and proper religious observance suggests that the stipulations pertaining to lamentation were not solely intended to regulate lay behavior.
\end{abstract}

Keywords: penitentials; keening; ritual purity; Old Testament law; early medieval Ireland

\section{Introduction}

One of the central elements of Irish funerary tradition up until the early twentieth century was the public performance of ritual lamentation or keening. (Ó Súilleabháin 1967, pp. 130-45; Bourke 1993, pp. 160-82; Lysaght 1997, vol. 108, pp. 65-82). This custom, which was regularly viewed with a mixed sense of fascination and abhorrence by outsiders, was for centuries vehemently opposed by the Catholic church authorities, who censured the "loud cries and howlings at wakes and burials" for being "unseemly", "savage", and essentially "unchristian." (See, e.g., Lysaght 1997, pp. 65-66; Ó Súilleabháin 1967, pp. 138-40).

While it is generally accepted that the roots of the Irish lament tradition can be traced back to ancient times, many aspects of the earliest historical evidence remain poorly understood. (Some of the earliest literary references to the practice are found in Tírechán's seventh-century account of the funeral obsequies of King Loíguire's daughters (Collectanea 26.16), as well as in Blathmac's long devotional composition from the mid-eighth century, in which the theme of keening is used to frame a poetical account of the Passion of Christ. (Bieler [1979] 2004, pp. 122-67; Carney [1964] 1989).) Among the most important sources in this regard are the Irish penitential documents, of which three in particular include lamentation as part of their treatment of various sins requiring some kind of expiation. These texts-the Canones Hibernenses or the Irish canons, the so-called Bigotian penitential, and the Old Irish penitential — have all been dated to the seventh and eighth centuries, and are part of a much larger corpus of penitential literature that was produced in Ireland and elsewhere in Europe throughout the early medieval period (Bieler [1963] 1975, pp. 160-75, 198-239, 258-77; McNeill and Gamer [1938] 1990). (Bieler's edition includes a translation of the Old Irish penitential by (Binchy [1963] 1975, pp. 258-77). Binchy's text is a revised version of (Gwynn 1914, pp. 121-95), corrigenda in (Gwynn 1938, pp. 245-49).) The medieval penitentials form a diverse collection of documents compiled to guide Christian communities in proper belief and conduct. Intended primarily as guides for confessors administering the sacrament of penance, the texts typically comprise lists of all possible types of sins together with specific penances for each offense. The system depended on a detailed consideration of the circumstances of each act, including the age, status, and mental disposition of the sinner, which were all taken into consideration when judging 
culpability and determining appropriate measures for reconciliation. While some of the earliest manuals only focus on topics concerning monastics, others also apply to secular clergy and members of the laity. On a whole, the penitential literature offers a bewildering inventory of theological, ethical, and legal issues that were considered to fall within the purview of the Church's moral authority. (Frantzen 1983; Firey 2008; Meens 2014).

In previous scholarship, references to keening in the Irish penitentials have been taken as one example of the ongoing efforts to eradicate pagan practices, which despite the spread of Christianity remained prevalent among the "nominally Christian people." (McNeill and Gamer [1938] 1990, p. 40). This was also the view of Ludwig Bieler, who argued without further discussion that the inclusion of keening in the earliest of the three sources, Canones Hibernenses, was motivated by the fact that it was "obviously considered a pagan custom." (Bieler [1963] 1975, p. 8; Cf. Gwynn 1914, p. 190 (note on §17)). Since Bieler, no systematic attempts have been made to revisit this issue, even though the need for such an appraisal has been acknowledged. (Lysaght 1997, p. 66). The purpose of the following analysis, therefore, is to offer a detailed examination of these sources in order to gain a better understanding of this evidence and its historical value.

Due to their normative nature, the penitential texts have been characterized as exceedingly formal, dogmatic, and derivative, and their utility as sources for cultural and social history remains an issue of ongoing debate. (See, e.g., Filotas 2005, pp. 1-64; Meens 2008, pp. 90-94; Pereira Farrell 2012, pp. 2-32). Distortions resulting from institutional agenda and clerical bias, alongside alterations, misunderstandings, and innovations introduced during the process of textual transmission, have led some scholars to conclude that the penitential prescriptions bear little relation to the lived experience of medieval Christians. (For an overview of the debate concerning pastoral literature in particular, see Filotas 2005, pp. 42-51). Much of this discussion pertains more broadly to the issue of medieval popular religion, and to the problems involved in determining the accuracy or authenticity of descriptions concerning pagan survivals and superstitions in the normative sources. (Van Engen 1986, vol. 91, pp. 519-52). The more negative view has highlighted the repetitive nature of the material, arguing that the documents tell more about contemporary literary conventions and external influence than about the local religious environment. (Boudriot 1928; Harmering 1997, vol. 27, pp. 445-56; see also Hen 1995, pp. 180-89). Others, focusing on the practice of early medieval penance in general, have taken the texts as examples of the "archaic and archaizing character of early medieval Christianity," (Meens 2008, p. 93), maintaining that the formality of penitential regulations is indicative of a rigid, abstract, and impersonal system that was applied mechanically irrespective of contextual circumstances. (See, e.g., McDonnell 1993, vol. 54, pp. 411-13).

As a response to these views, scholars including Allan Frantzen, Bernadette Filotas, and Rob Meens among others, have claimed that the distrust of penitential literature commonly stems from "too-easy generalizations," (Meens 2014, p. 8). which overlook the complexity of this material and the variety of contextual factors-chronological, regional, codicological, and intellectual - that all played a part in the compilation, circulation, and use of the penitential texts. From this perspective, as argued by Frantzen, the "combination of flexibility and conservatism," (Frantzen 1983, p. 17) which in some ways makes the interpretation of this evidence so challenging, can also help us better understand the ideological background of individual texts, as well as their use and intended audience. (See also Filotas 2005, p. 9; Meens 2014, pp. 6-9; Flechner 2016a, pp. 77-95). The need to pay attention to both continuities and variations in the analysis of the penitential texts also holds true in the present case, where the three sources, demonstrably belonging to the same local textual tradition, can be shown to frame the issue of the 'sinfulness' of ritual lamentation in different ways. Thus, although the prescriptive articulations against keening are all predicated upon particular conceptions of sin, decorum, and orthopraxy that reflect the specific concerns of the ecclesiastical elite, these concerns were not static or uniform. Instead of simply evidencing the Church's zealous attempt to abolish pagan customs as has previously been assumed, the treatment of the theme in these texts affords an insight into the ongoing intellectual negotiations of the Irish literati who sought to bring 
the imperatives drawn from Scripture and other Church authorities to bear on the realities of their own social world.

\section{Contextualizing the Penitential Texts}

The first Irish penitential handbooks have been dated to the late sixth century. In Ireland and in Wales, the emergence of this new literary form was preceded by the compilation of collections penitential decisions, which, albeit concerned with issues of ecclesiastical discipline, were not primarily for pastoral use. (See (Bieler [1963] 1975, pp. 3-5)). While all of the penitential texts are products of a monastic milieu, the majority of them were evidently intended for a wider audience. According to Frantzen, between the late sixth and the early ninth centuries, the Irish penitential texts "seem to mark stages of a progression toward greater concern for penance among lay people," (Frantzen 1983, p. 36) possibly reflecting the process of Christianization and the consolidation of the Church's authority in society. (Cf. Filotas 2005, p. 42; Pereira Farrell 2012, p. 3; see also Flechner 2016b, pp. 41-59; Etchingham 2016, pp. 181-207). On a whole, the extant documentary evidence appears to support this view, but the question as to what extent the provision of pastoral care extended to all members of the laity during this period is still difficult to ascertain. Colmán Etchingham, for instance, has claimed that the sources pertaining to this issue may be taken to indicate that regular pastoral ministry primarily benefited a select minority, namely a group of ecclesiastical dependents who were socio-economically bound to serve the Church and entitled to receive its services in return (Etchingham [1999] 2002, pp. 239-89). Those who have envisioned a more comprehensive system, however, have argued that already by the early eighth century, pastoral care was accessible to the entire population who, "whatever the vagaries of individual belief and morality, would have regarded themselves as Christian, with as good a chance as any of gaining entry to heaven." (Boyle 2021, p. 154; See also Sharpe 1992, pp. 81-109).

In the highly stratified social hierarchy of early medieval Ireland, the literati belonged to the higher echelons of the society, and the documents produced by this "self-confident, highly-educated and articulated intellectual élite" (Boyle 2021, p. 1) bespeak a conscious effort to establish the power and special prerogatives of the Church while also asserting their own status and learning. (On the early Irish social system, see (Aitchison 1994, vol. 49, pp. 45-75).) With regard to the normative sources, one of the most distinctive features of this project was the manner in which the conceptions developed in this learned environment drew on Mosaic Law to fashion various aspects of Irish society and culture on the authoritative model of the Old Testament. (Kottje 1964; Ó Corráin et al. 1984, vol. 3, pp. 382-438; see also Meens 2000, pp. 67-77; Boyle 2021). The process of turning the rules of the Pentateuch into practical directives entailed that Mosaic Law was often followed literally, to the extent that the members of the learned classes were repeatedly identified with the Old Testament priests and Levites, with their status, duties, and privileges defined accordingly. (Ó Corráin et al. 1984). While much of this influence can be identified in direct citations, Ó Corráin, Breatnach and Breen have pointed out that it is more often "found in the assumptions of the lawyers rather than in any extensive explicit statements." (Ó Corráin et al. 1984, p. 394). The adoption and adaptation of the biblical rules was thus part of an all-encompassing strategy, by which the Irish grafted their Christian identity onto the Old Testament past. (Meens 2000, p. 77).

As illustrated in the following, this profound interest in the Mosaic prescriptions, and the Levitical purity rules in particular, is also reflected in the earliest text dealing with ritual lamentation, Canones Hibernenses. It is noteworthy that this collection, as pointed out by Bieler, is not a penitential handbook in a conventional sense, but rather a compilation of "several separate pieces of partly penitential, partly general ecclesiastical and partly even purely secular legislation." (Bieler 1966, p. 337). (The other canons in the compilation deal with a variety of topics including commutations of long penances, the offering of tithes, offences against ecclesiastics, and regulations concerning dogs.) When compared to the two later sources, then, it is possible to demonstrate that the overall rationale of the tract 
included in the Canones was defined by very specific learned interest, which also made its intended audience much more limited.

\section{Impurity, Pollution, and Sin: Canones Hibernenses}

The Canones Hibernenses has been dated with relative certainty to around the midseventh century (Bieler [1963] 1975, p. 9). The collective name was given to these texts by Friedrich Wilhelm Wasserschleben; see his Die Bussordnungen der abendländischen Kirche: nebst einer rechtsgeschichtlichen Einleitung (Wasserschleben 1851, pp. 136-44). Of the six canons, Canon I follows the conventions of penitential literature especially in outlining a system where each offense is matched with a suitable penitential exercise, usually a period of fasting on bread and water. The reference to ritual lamentation in this Canon comes at the very end of a list of 29 decrees, which is given below in its entirety following Bieler's translation:

Of the decision of an Irish synod and of Gregory Nazianzen. A discourse concerning unnumbered sins.

1. The penance for parricide is fourteen years, or half as long if [it was committed] on account of ignorance, on bread and water and with satisfaction.

2. This is the penance for homicide, seven years. It shall be performed on bread and water.

3. The penance for homicide [is] seven years on bread and water, or as Monochoma says, ten.

4. This is the penance of a wizard, or of one who has vowed himself to evil, or a malefactor or of a hawker, or of a cohabiter, or of a heretic, or of an adulterer: seven years on bread and water.

5. The penance for intercourse with a woman, seven years on bread and water. The penance for intercourse with a neighbor woman, fourteen years or nine.

6. The penance for the destruction of an embryo of a child in the mother's womb, three and a half years.

7. The penance for the destruction of flesh and spirit, seven and a half years on bread and water, in continence.

8. The life price for the destruction of an embryo and the mother, twelve female slaves.

9. Twelve fowls or thirteen shekels are the value of each female slave.

10. The life-price for the destruction of the child and the mother, twelve female slaves.

11. The penance for a mother's destruction of her own child, twelve years on bread and water.

12. The penance for drinking blood or urine, seven and a half years on bread and water, followed by the imposition of the hand of the bishop.

13. The penance for eating horseflesh, four years on bread and water.

14. The penance for eating flesh which dogs have been eating, forty days on bread and water.

15. The penance for eating the flesh of a dead beast, forty-two days on bread and water.

16. The penance for the illicit drinking of [what has been contaminated by] a dog, one year.

17. The penance for the illicit drinking of [what has been contaminated by] an eagle or a crow or a daw or a cock or a hen, fifty days on bread and water.

18. The penance for the illicit drinking of [what has been contaminated by] a cat, five days on bread and water and a special fast.

19. The penance for the illicit drinking of [what has been contaminated by] the carcass of a beast, forty days and nights on bread and water.

20. The penance for the illicit drinking of [what has been contaminated by] the dead body of a mouse, seven days on bread and water.

21. The penance for the illicit drinking of [what has been contaminated by] a layman or a laywoman, fifty days on bread and water.

22. The penance for eating or sleeping in the same house or the same bed with a layman or a laywoman, forty days on bread and water. 
23. The penance for the illicit drinking of [what has been contaminated by] a pregnant servant woman or by him who cohabits with her (glantelle prignantis uel cohabitatoris sui), forty days on bread and water.

24. The penance for eating in the same house or the same tent (?) with them, forty days on bread and water.

25. The penance for sleeping in the same house with them, twenty days on bread and water.

26. The penance for the wailing ... (bardigi capalbiae) after [the death of] a layman or a laywoman, fifty days on bread and water.

27. If [the dirge is sung] after [the death of] a servant woman with child, or after [the death of] him who cohabits with her, forty days on bread and water.

28. If after [the death of] a cleric of a parish, twenty days on bread and water.

29. If after [the death of] an anchorite or a bishop or a scribe or a great prince or a righteous king, fifteen days on bread and water. (Bieler [1963] 1975, pp. 160-63).

The list as it stands has no direct precedents in penitential literature, although the decrees concerning polluted food (\$\$12-23 above), for example, are similar to those found in the contemporary penitentials of Cummean and Theodore, as well as in the so-called Canons of Adamnán. On this theme in penitential literature, see further (Meens 1995, vol. 4, pp. 3-19; Wagner 2004, pp. 59-67). In this instance, the notion of ritual purity that underlies these dietary prohibitions is of key importance, since it essentially defines the rationale of this seemingly disjointed list of "unnumbered sins" as a whole.

In the Old Testament, the interdictions set in place to protect the sacred places, people and objects from ritual defilement constituted the most important mechanism by which the contractual relationship between Yahweh and the people of Israel could be maintained. Sin, in essence, implied any transgression against the rules and commandments that Yahweh had given to his people: such offences were disruptive to the social order and were thereby in direct violation of the covenant. The remedy for sin must be sought before the Lord because all sins threatened His holy presence and endangered the solidarity of the whole community. Conversely, the adherence to religious precepts was indicative of an individual's or whole community's acceptance of God, and hence ensured that they would also be accepted by Him. (On defilement as a violation against holiness and the covenant, see (Schwartz 2000, pp. 47-59; Lam 2018, vol. 12, p. e12260).)

The sophisticated exegetical system defining the spheres of the holy and the profane, and the clean and the unclean, in the cultic life of the Israelites was laid out in the priestly writings of the Pentateuch. The dynamic spectrum of graded impurity formulated therein pertained to people, places, and activities alike (Wright 1991, pp. 150-81; Jenson 1992; Milgrom 2000, pp. 29-32; Hundley 2013, pp. 749-67). One of the most fundamental categorizations in this scheme concerned the division between unequivocally prohibited 'moral' impurities and tolerated 'ritual' impurities, both of which were further divided into subgroups depending on the nature and intensity of the offense (Klawans 1998, vol. 29, pp. 391-415; Wright 1991, pp. 151-52). Transgressions that caused moral impurity entailed an active violation of God-ordained law, and could arise from both intentional or unintentional actions. Ritual impurity on the other hand denoted things that were temporarily or relatively impure as stated in the Law of Moses. The state of ritual impurity could be contracted through contagion either directly or indirectly, and these circumstances also had a bearing on how severe any given pollution was perceived to be (Wright 1991).

For the present purpose, this schematic model is especially useful in elucidating the structure of Canon I, which appropriates the basic distinction between moral and ritual impurities in its treatment of the different transgressions. First, decrees $\$ \$ 1-11$ focus on prohibited moral impurity, which in this instance is illustrated by various Old Testament abominations including homicide (Ex. 21:12), witchcraft (Deut. 18:10-12), idolatry (Deut. 12:31), dishonest trading (Lev. 19:35-36), and illicit sexual unions (Lev. 18:20). (The inclusion of the hawker in this list reflects the notion that deceit and dishonesty, for instance the manipulation of scales, was in itself considered morally defiling; see (Klawans 
1998, pp. 406-409).) The issue of inadvertence is particularly highlighted in the case of abortion, where the severity of the offense is determined by the intention of the perpetrator as well as the status of the casualty:

\section{§1-11 Moral impurity}

$\S 1$ Parricide (intentional or unintentional)

$\S \S 2-3$ Homicide

$\S \S 4-5$ Witchcraft, heresy, idolatry, evil deeds, deceit, illicit sexual relations $\S \S 6-11$ Abortion

Destruction of an embryo (intentional, non-human casualty)

Destruction of flesh and spirit (intentional, human casualty)

Destruction of embryo and mother (intentional, non-human casualty [embryo]; unintentional, human casualty [mother])

Destruction of child and mother (intentional, human casualty [child]; unintentional, human casualty [mother])

Mother's destruction of her own child (intentional, human casualty [child]; murder of close kin [mother-child])

Decrees $\$ \S 12-29$, in turn, elaborate on degrees of ritual impurity that has been transmitted through contact with something deemed ritually unclean. These are instances where such forbidden items have been directly consumed, or where contagion has resulted from secondary contact with unclean beings:

\section{§12-29 Ritual impurity}

$\S \S 12-15$ Ingestion of unclean things

Liquid (blood or urine)

Solid matter (horseflesh)

Things unclean by contamination (eaten by dogs)

Things unclean by nature (animal carcass)

§§16-18 Secondary contact, contagion by live animals

Drinking (dog, birds, cat)

§19-20 Secondary contact, contagion by dead animals

Drinking (beast, mouse)

$\S \S 21-25$ Secondary contact, contagion by live humans

Drinking/eating/sleeping (laypeople, pregnant woman and her cohabitor)

§26-29 Secondary contact, contagion by dead humans

Laypeople; pregnant woman and her cohabitor; cleric; anchorite, bishop, scribe, great prince, righteous king

The systematic manner in which all of these regulations concerning communicable impurity have been modelled on the rules found in Mosaic Law indicates that the injunctions against mourning in \$\$26-29 were not primarily motivated by the need to curb a 'pagan' custom (cf. Sharpe 1979, vol. 30, p. 78). Instead, the performance of ritual lamentation serves here as an example of a situation where ritual defilement resulting from contact with the dead could arise. According to both Leviticus and Numbers, impurities related to sex, disease, and death were particularly potent because they could contaminate objects and persons in both direct and indirect ways. Thus, defilement could occur if one came into contact with the source itself or with items which it had touched, as in $\$ \S 21-23$ (cf. Lev. 15:1-12,19-27), or if one entered, ate, or slept in a house where the source of impurity was present, as in $\S \S 22,24-25$ (cf. Lev. 14:46-47). In the same way, death-related impurity could also be contracted by either directly touching a dead body or by merely being in its presence in a confined space (Num. 19:11-15). (The prohibitions against being in the same confined space with the source of impurity reflect the principle of 'tent impurity', 
discussed in (Noam 2010, vol. 1, pp. 65-103). For a detailed examination of the rules and prohibitions relating to the communicability of impurity in this regard, see (Wright 1987, pp. 163-228).)

Following from these principles, it becomes evident that the obscure expression bardigi capalbiae in $\$ \$ 26-29$ refers to the event of collective mourning where laments were being performed in the presence of the deceased, rather than to the actual act of lamentation itself. Since the members of the laity are identified as sources of impurity in $\S \S 21-25$, the perceived risk of becoming ritually defiled in such a situation must have pertained to ecclesiastics, to whom the maintenance of boundaries between holy and profane was the foremost indication of their special sanctified status. (For a detailed discussion of this notion in relation to the Céli Dé, see (Wagner 2004).) With regard to death-related impurity in particular, the biblical regulations were unequivocal: those consecrated to the Lord should not defile themselves by coming into contact with the dead, because by doing so they violated their vows of separation (Num. 6:6-12; Lev. 21:1-4, 11). Apart from Canon I, the acknowledgment of this rule is found in some other early Irish sources as well. The seventh-century Vita Columbae (III.6) mentions how Saint Columba visited one of his monks who was on his deathbed, and after blessing him hastened out "for he wished not to see the man die." (Sharpe 1995, p. 210). The Old Irish text known by the title The Monastery of Tallaght, also includes injunctions against being under the same roof with the dead:

to eat a meal with a dead man (though saintly) in the house is forbidden [ ... ]. Even one in orders who brings the sacrament to a sick man is obliged to go out of the house at once thereafter, that the sick man die not in his presence; for if he be present in the house at the death, it would not be allowable for him to perform the sacrifice until a bishop should consecrate him. (§65: Praind dano do tomailt la marb hi tig ceth naob [ ... ]. Cid ind fer graid dobeir sacrafic dond fir galir dlegair dó daul astig statim iarum ne presenti illo moritur. Ar diambe hi fiadnaisi ind bais istig nicotaldad dó oifrenn do denam conidcoisrecad epscob (Gwynn and Purton 1911-1912, p. 153).)

Likewise the Latin Rule of Tallaght advises against coming into contact with food that has been polluted by death:

The food that is in a house when any one dies in it ought to be blessed and distributed among the poor: because food ought not to be kept in the same house with a sick man, or eaten in the same house with a dead man, however holy he may be. (§43: Biad bis in domu quando moritur aliquis in a consecrare et pauberibus dividere bebet, ar cibus in una domu cum infirmo custodire vel cum mortuo, quamuis sanctus sit, manducari non debet (Gwynn 1927, pp. 74-75).)

The qualification expressed in all of these sources with regard to the deceased-namely, that the holiness of the dead person does not negate the pollution generated by the corpseis particularly interesting in light of $\S \S 26-29$ of Canon I, which distinguish between degrees of defilement depending on the social status of the individual being mourned. The manner in which the Mosaic directives are here adapted to the local socio-cultural circumstances indicates that even though these regulations on a whole had a very specific aim, audience, and scope, their approach to the divine law was nevertheless practical (cf. Wagner 2004, p. 66). It was only when the material from Canon I became incorporated into the later penitential handbooks that the decrees dealing with mourning were reworked to suit the needs of pastoral care, extending their spiritual and pragmatic authority to the wider Christian community.

\section{Controlling the "Clamour Aroused by Grief": The Bigotian and the Old Irish Penitential}

The so-called Bigotian penitential, dated around the eighth century, survives in two continental manuscripts, both of which include a variety of penitential material (Bieler [1963] 1975, pp. 12-13; Pereira Farrell 2012, pp. 77-79). The Bigotian is heavily dependent on another early Irish penitential ascribed to Cummean, which it follows in its grouping of 
items according to Cassian's scheme of eight principal vices. The main passages in the Bigotian where explicit reference to the authority of the Canones is made are found under two main headings: gluttony ( $g$ ula) for dietary restrictions, and anger (ira) for lamentation. (The section on gluttony includes $\S \S 12-23$ of Canon I, except $\$ 13$ on the eating of horseflesh; (Bieler [1963] 1975, pp. 216-19).) The relevant section concerning the latter reads in Bieler's translation as follows:

Of clamour, the canons of the fathers:

1. To raise one's voice in shouting, if the person addressed is far away from the speaker, or if one greets a deaf person, is not at all forbidden. Shouting, however, that is prompted by quick temper shall be healed by silence and fasting for such a period as the priest may decide; also, we must not pass over clamour aroused by grief, of which we will say a few things.

2. The penance for the wailing of a female dependant (bardicationis glandellae) after the death of a layman or laywoman, fifty days on bread and water;

3. if (the dirge is sung) after (the death of) a servant woman who died in childbirth, or of him [or her] (cohabitatorem uel cohabitatricem) who cohabits with her, they being believers, forty days on bread and water;

4. if after (the death of) a cleric of the parish, twenty days on bread and water;

5. if after (the death of) an anchorite or a scribe or a bishop or a great prince or a great king, fifteen days on bread and water;

6. if any nun becomes excited and shouts with sounds of this sort, she shall be corrected with double the penance prescribed above. (Bieler [1963] 1975, pp. 230-31).

The reframing of the issue of ritual lamentation as a sin related to anger highlights the problematic nature of the 'clamour aroused by grief' as well as its broader negative consequences. Dramatic mourning was a serious concern for early Christian authorities, many of whom saw it as not only shameful, but also potentially dangerous and destructive. From a theological viewpoint, the passionate displays of public grief were condemnable because they seemed to deny the promise of the resurrection, but within the community, the seemingly uncontrollable expressions of emotion could also give rise to more extreme actions including strife or even bloodshed. (See, e.g., (Alexiou 1974, pp. 24-35; HolstWarhaft 1992; Lansing 2008, pp. 99-122).) The manner in which the Bigotian addresses this kind of 'clamour' as being different from the worldly sadness treated as a sign of tristitia signals that the penitential injunctions may have sought to take both of these aspects into account, by aiming to control such excessive expression of emotion which could be socially disruptive and also went against the Christian virtues of hope, fortitude, and temperance. Given the importance of communal mourning in the social fabric of early Irish society, however, the compilers of the Bigotian were faced with the particular challenge of acknowledging the more positive aspects of the practice as well. Hence immediately after the passage in question the text includes the following qualification, drawing directly on the authority of Scripture:

Concerning the making of lamentation and its being reckoned as good merit, it is said in the law:

Jacob the son of Isaac was lamented for forty days in Egypt and for a whole week in the land of Canaan; and so was Christ in the New (Testament), the women wept for Him; and it is found written in the Canon with almost innumerable examples of the Scriptures, and for whom no lament is made to him it is reckoned as bad merit. (Bieler [1963] 1975, pp. 230-31)

Following the Canones, the Bigotian considers the social status of the deceased as a mitigating factor in determining the severity of the offense, but the passage also sheds some further light on the position of the individuals singled out in this context. Bieler suggested that the 'female dependant' (glandella) performing the lament may plausibly be equated with clientella, who in the sixth-century Penitential of Finnian (\$27) and the closely related Penitential of St. Columbanus (B.8) is identified as the former partner of an ecclesiastic, who 
has begotten a child with her after taking the vow of celibacy (Bieler [1963] 1975, pp. 82, 100. (For discussion of the term, see $243-44$ note 12 ). Since it was understood that the woman had by her own actions also breached a vow of virginity, the term may be taken to denote someone who had acquired a special status within the Christian community as a 'repentant female spouse', undergoing penance and living in a paramonastic state alongside other 'believers' who were serving the Church in lawful matrimony (cohabitator uel cohabitatricem fidem habentem) (Etchingham [1999] 2002, pp. 309-10). (With regard to the category of 'believers' I am here following Etchingham's translation of the relevant section of §3: "If after a female repentant spouse dying in childbirth or after a male or female spouse having the faith ... "). From this perspective, it is possible that the reference made in $\S 3$ to the woman dying in childbirth (glandellam morientem in partu) should be interpreted in conjunction with $\S 2$ as referring specifically to such an individual, and not just any 'servant woman' as could be inferred from Bieler's translation.

While the distinction between laicus/laica of $\$ 1$ and glandella, cohabitator and cohabitatrix of $\S 3$ rests on the Christian commitment of the latter, it is not entirely clear whether laicus in this instance should be interpreted as a 'pagan'. Sharpe's argument that this is the only option since "keening was regarded by the Church as a pagan practice" and "the laity were not regarded as unclean" (Sharpe 1979, p. 78) is not supported in light of the analysis presented above, and it is possible that these categories are used instead to distinguish between degrees of sinfulness or worldliness among the members of the wider Christian community. Thus, those who had accepted a quasi-monastic penitent lifestyle were not only spiritually but also physically committed to the prerequisites of Christian faith, unlike the members of the laity who in the words of Etchingham, "were most commonly regarded as constituting a persistently sinful existence which, while not exactly pagan, was not truly Christian either." (Etchingham [1999] 2002, p. 316; Follett 2006, pp. 80-81).

That access to spiritual direction was one of the foremost qualities defining the status of 'penitent folk' in relation to other members of the laity is also illustrated in the late eighth-century Old Irish penitential, the only extant Irish penitential written in the vernacular. Closely related to the Bigotian, the Old Irish penitential incorporates some additional material found in the penitentials of Cummean and Theodore, and for the most part follows the earlier authoritative tradition closely (Bieler [1963] 1975, p. 49). In his edition, Gwynn remarked that the text "strikes one as intended for monastic use" (Gwynn 1914, p. 130). (The association of the text with the Céli Dé community at Tallaght has been discussed by (Follett 2006, pp. 124-26).) However, it is evident that from a pastoral viewpoint its reach was conceived more broadly:

$\S 16$ If anyone raises his voice in speaking to someone at a distance or to a deaf man, there is [no] penance. If the raising of his voice is attended with anger, whether at a distance or near by, penance is done according to the sin and the transgression. If it be illness that provokes any outcry, it is not to be passed over for the moment.

\$17 A married woman or a penitent nun (cetmunter no caillech aithirgi) who makes lamentation over a layman or laywoman (for laiech nó laithes), fifty nights' penance. If it be over a married woman or a penitent nun who dies in childbed, or a member of the household (fiur muindtiri), forty nights' penance. If over a cleric of the laity, twenty nights' penance. If over a bishop or king or confessor (anmcarait) or ruler of a chief town, fifteen nights' penance.

$\S 18$ If it be a novice (mac-cleiriuch) who happens to commit one of the offences here mentioned, he has double penance, compared with a married woman. (Gwynn 1914, pp. 170-71. Binchy's translation of $§ 17$ ("Appendix," 273) reads "a married woman or a concubine (?)" assuming that difference between the two lies in their lawful marital status.).

The terms cetmunter 'married woman' and caillech aithirgi 'penitent nun' in $§ 17$ hark back to the difference drawn between cohabitatrix and glandella in the Bigotian. As individuals having 'faith', both of them are considered equal with other members of a group that was under same spiritual authority and thus represented one 'family' or commu- 
nity (muinter) of Christian religious. (On the meaning of muinter in this context, see also (Follett 2006, pp. 175-79).) The socio-economic status of each member within this wider ecclesiastic community was determined by duties that bound them to the Church and allowed them to receive pastoral guidance in return (Etchingham [1999] 2002). While many of those belonging to this group may have actually lived together within the ecclesiastical enclosure, in general terms, the muinter could also extend to tenants living on church lands. Regardless of whether the relationship was more symbolic or factual, however, this kind of 'spiritual kinship' created a bond of social obligation, which at the moment of death became ritually expressed in the act of communal mourning. In principle, then, a lament performed by a Christian was condemnable, but still somewhat less so if performed for other members of the same ecclesiastic 'family', or for those who merited it due to their social standing alone.

\section{Conclusions}

As one of the most pervasive dilemmas of Christian faith, the question of sin and reconciliation has from the earliest times been of paramount importance, and also had very real consequences to all believers. The various responses to this issue found in the penitentials reflect the Church's attempt to address the problem in both theological and practical terms, yet the picture that they paint is not uniform.

The passages on ritual lamentation in the Irish penitentials have come down to us in texts written over a period of time spanning approximately from the mid-seventh century to the end of the eighth. Despite belonging within the same textual tradition, they also bear witness to the ways in which their authors or compilers engaged in active dialogue with the materials at their disposal. In seeking to shape the Levitical prescriptions of the Old Testament into practical directives, the Canones hibernenses presents lamentation as an example of a situation where various degrees of ritual defilement could occur. The preoccupation with the maintenance of symbolic boundaries between holy and unholy bespeaks the interests of those to whom the state of ritual purity was in itself the main theological foundation of imitatio Dei. As these principles became incorporated into the Bigotian and the Old Irish penitential, a shift of emphasis occurred that allowed for the reframing of lamentation not in terms of potential outwardly threat to one's holiness, but rather as an expression of excessive negative emotion. Accordingly, the practice became viewed as indicative of an inner disposition that was harmful to all Christians, and could also lead to more serious offences committed in either thought, word, or deed.

If sins were never private affairs for early Irish Christians, the same could also be said of death. The notion of a reciprocal contractual relationship that made each Christian accountable for their actions to God was also a fundamental element of the fabric of the earthly community, where the social ties which defined the individual's status and his or her relations with their fellow men became actualized and symbolically articulated in rituals of communal mourning. While the compilers of the penitentials sought to take into account all the mitigating circumstances for each offense, they also had to negotiate a balance between the authority of their normative tradition and the realities of the everyday lives of the believers under their pastoral guidance. The glimpse that we can get of this ongoing negotiation should serve as a reminder that these prescriptions were not merely a dead letter, but rather an essential part of lived religion in early medieval Ireland.

Funding: This research was funded by the Alfred Kordelin Foundation.

Institutional Review Board Statement: Not applicable.

Informed Consent Statement: Not applicable.

Acknowledgments: I am grateful for Roy Flechner for kindly sharing copies of his publications with me, and for the anonymous reviewers for their helpful feedback. An earlier version of this paper was presented at the Irish Conference of Medievalists in 2018.

Conflicts of Interest: The author declares no conflict of interest. 


\section{References}

Aitchison, Norman B. 1994. Kingship, society, and sacrality: Rank, power, and ideology in early medieval Ireland. Traditio 49: 45-75. [CrossRef]

Alexiou, Margaret. 1974. The Ritual Lament in Greek Tradition. Cambridge: Cambridge University Press.

Bieler, Ludwig. 1966. The Irish penitentials: Their religious and social background. Studia Patristica 8: 329-39.

Bieler, Ludwig, ed. 1975. The Irish Penitentials. Ludwig Bieler, trans. Scriptores latini Hiberniae V. Dublin: Dublin Institute for Advanced Studies. First published 1963.

Bieler, Ludwig, ed. 2004. The Patrician Texts in the Book of Armagh. Ludwig Bieler, trans. Scriptores latini Hiberniae X. Dublin: Dublin Institute for Advanced Studies. First published 1979.

Binchy, Daniel A. 1975. Appendix: The Old-Irish penitential. In The Irish Penitentials. Edited and translated by Ludwig Bieler. Scriptores latini Hiberniae V. Dublin: Dublin Institute for Advanced Studies, pp. 258-77. First published 1963.

Boudriot, Wilhelm. 1928. Die Altgermanische Religion in der Amtlichen Kirchlichen Literatur des Abendlandes vom 5. bis 11. Jahrhundert. Untersuchungen zur allgemeinen Religionsgeschichte 2. Bonn: Röhrscheid.

Bourke, Angela. 1993. More in anger than in sorrow: Irish women's lament poetry. In Feminist Messages: Coding in Women's Folk Culture. Edited by Joan Newlon Radner. Urbana and Chicago: University of Illinois Press, pp. 160-82.

Boyle, Elizabeth. 2021. History and Salvation in Early Medieval Ireland, Kindle edition. London: Routledge.

Carney, James, ed. 1989. The Poems of Blathmac Son of Cú Brettan, together with the Irish Gospel of Thomas and a Poem on the Virgin Mary. James Carney, trans. Irish Texts Society XLVII. Dublin: Irish Texts Society. First published 1964.

Etchingham, Colmán. 2002. Church Organisation in Ireland A.D. 650 to 1000. Maynooth: Laigin Publications. First published 1999.

Etchingham, Colmán. 2016. Conversion in Ireland. In The Introduction of Christianity into the Early Medieval Insular World: Converting the Isles I. Edited by Roy Flechner and Máire Ní Mhaonaigh. Turnhout: Brepols, pp. 181-207.

Filotas, Bernadette. 2005. Pagan Survivals, Superstitions and Popular Cultures. Toronto: Pontificial Institute of Medieval Studies.

Firey, Abigail, ed. 2008. A New History of Penance. Leiden: Brill.

Flechner, Roy. 2016a. Normative texts as sources for conversion to Christianity in Europe. In Contesting Inter-Religious Conversion in the Medieval World. Edited by Yaniv Fox and Yosi Yisraeli. London: Routledge, pp. 77-95.

Flechner, Roy. 2016b. Conversion in Ireland: Reflections on the state of the art. In The Introduction of Christianity into the Early Medieval Insular World: Converting the Isles I. Edited by Roy Flechner and Máire Ní Mhaonaigh. Turnhout: Brepols, pp. 41-59.

Follett, Westley. 2006. Céli Dé in Ireland: Monastic Writing and Identity in the Early Middle Ages. Studies in Celtic History 23. Woodbridge: The Boydell Press.

Frantzen, Allen J. 1983. The Literature of Penance in Anglo-Saxon England. New Brunswick: Rutgers University Press.

Gwynn, Edward J., ed. 1914. An Irish penitential. Ériu 7: 121-95.

Gwynn, Edward J., ed. 1927. The Rule of Tallaght. Dublin: Hodges, Figgis.

Gwynn, Edward J. 1938. Notes on the Irish penitential. Ériu 12: 245-49.

Gwynn, Edward J., and Walter John Purton, eds. 1911-1912. The monastery of Tallaght. Proceedings of the Royal Irish Academy 29C: 115-79.

Harmering, Dieter. 1997. Anthropologie historique ou herméneutique littéraire? Une critique ethnographique des sources médiévales. Ethnologie Française 27: 445-56.

Hen, Yitzhak. 1995. Culture and Religion in Merovingian Gaul. Leiden: Brill.

Holst-Warhaft, Gail. 1992. Dangerous Voices: Women's Laments and Greek Literature. London: Routledge.

Hundley, Michael B. 2013. Sacred spaces, objects, offerings, and people in the priestly texts: A reappraisal. Journal of Biblical Literature 132: 749-67.

Jenson, Philip Peter. 1992. Graded Holiness: A Key to the Priestly Conception of the World. Journal for the Study of the Old Testament Supplement Series 106; Sheffield: JSOT Press.

Klawans, Jonathan. 1998. Idolatry, incest, and impurity: Moral defilement in ancient Judaism. Journal for the Study of Judaism 29: 391-415. [CrossRef]

Kottje, Raymund. 1964. Studien zum Einfluß des Alten Testamentes auf Recht und Liturgie des frühen Mittelalters, 6.-8. Jahrhundert. Bonner Historische Forschungen, hg. von Max Braubach 23. Bonn: Ludwig Röhrscheid Verlag.

Lam, Joseph. 2018. The concept of sin in the Hebrew Bible. Religion Compass 12: e12260. [CrossRef]

Lansing, Carol. 2008. Passion and Order: Restraint of Grief in the Medieval Italian Communes. Ithaca and London: Cornell University Press.

Lysaght, Patricia. 1997. Caoineadh os cionn coirp: The lament for the dead in Ireland. Folklore 108: 65-82. [CrossRef]

McDonnell, Kilian. 1993. The Summae confessorum on the integrity of confession as prolegomena for Luther and Trent. Theological Studies 54: 405-26. [CrossRef]

John T. McNeill, and Helena M. Gamer, transs. 1990, Medieval Handbooks of Penance: A Translation of the Principal Libri Poenitentiales and Selections from Related Documents. New York: Columbia University Press. First published 1938.

Meens, Rob. 1995. Pollution in the early middle ages: The case of the food regulations in the penitentials. Early Medieval Europe 4: 3-19. [CrossRef]

Meens, Rob. 2000. The uses of the Old Testament in medieval canon law: The Collectio Vetus Gallica and the Collectio Hibernensis. In The Uses of the Past in the Early Middle Ages. Edited by Yitzhak Hen and Matthew Innes. Cambridge: Cambridge University Press, pp. 67-77. 
Meens, Rob. 2008. The historiography of early medieval penance. In A New History of Penance. Edited by Abigail Firey. Leiden: Brill, pp. 73-95.

Meens, Rob. 2014. Penance in Medieval EUROPE, 600-1200. Cambridge: Cambridge University Press.

Milgrom, Jacob. 2000. The dynamics of purity in the priestly system. In Purity and Holiness: The Heritage of Leviticus. Edited by Marcel Poorthuis and Joshua J. Schwartz. Jewish and Christian Perspectives Series; Leiden: Brill, vol. 2, pp. 29-32.

Noam, Vered. 2010. Ritual impurity in Tannaitic literature: Two opposing perspectives. Journal of Ancient Judaism 1: 65-103. [CrossRef] Ó Corráin, Donnchadh, Liam Breatnach, and Aidan Breen. 1984. The Laws of the Irish. Peritia 3: 382-438. [CrossRef]

Ó Súilleabháin, Séan. 1967. Irish Wake Amusements. Dublin: The Mercier Press.

Pereira Farrell, Elena. 2012. Taboos and Penitence: Christian Conversion and Popular Religion in Early Medieval Ireland. Ph.D. dissertation, University College Dublin, Dublin, Ireland.

Schwartz, Baruch J. 2000. Israel's holiness: The Torah traditions. In Purity and Holiness: The Heritage of Leviticus. Edited by Marcel Poorthuis and Joshua J. Schwartz. Jewish and Christian Perspectives Series; Leiden: Brill, vol. 2, pp. 47-59.

Sharpe, Richard. 1979. Hiberno-Latin laicus, Irish láech and the devil's men. Ériu 30: 75-92.

Sharpe, Richard. 1992. Churches and communities in early medieval Ireland: Towards a pastoral model. In Pastoral Care before the Parish. Edited by John Blair and Richard Sharpe. Leicester: Leicester University Press, pp. 81-109.

Richard Sharpe, trans. 1995, Adomnán of Iona: Life of St Columba. London: Penguin Classics.

Van Engen, John. 1986. The Christian Middle Ages as an historiographical problem. American Historical Review 91: 519-52. [CrossRef]

Wagner, S. Morgyn. 2004. Ritual Impurity and the Céli De: Sin, Theology, and Practice in the Eighth and Ninth Centuries. Ph.D. dissertation, University of Edinburgh, Edinburgh, UK.

Wasserschleben, Friedrich Wilhelm, ed. 1851. Die Bussordnungen der Abendländischen Kirche: Nebst Einer Rechtsgeschichtlichen Einleitung. Halle: Graeger.

Wright, David P. 1987. The Disposal of Impurity: Elimination Rites in the Bible and in Hittite and Mesopotamian Literature. Society of Biblical Literature Disseration Series 101; Atlanta: Scholars Press.

Wright, David P. 1991. The spectrum of priestly impurity. In Priesthood and Cult in Ancient Israel. Edited by Gary A. Anderson and Saul M. Olyan. Journal for the Study of the Old Testament Supplement Series 125; Sheffield: JSOT Press, pp. $150-81$. 